\title{
Revalidation of Organ's Organisational Citizenship Behaviour Scale in Banking Sector
}

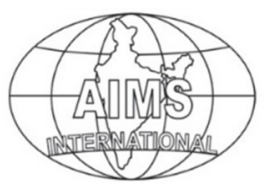

DOI: $10.26573 / 2018.12 .2 .1$

Volume 12, Number 2

May 2018, pp. 81-97

\author{
Parul Mahajan \\ School of Management, MIET \\ Jammu, India \\ (parulm.mba@mietjammu.in)
}

This study seeks to explore the Organisational Citizenship Behaviour (OCB) which is regarded as the prerequisite for the success of any organisation. OCB includes those behaviours which are above and beyond their formal call of duty and contribute towards the organisational effectiveness. With this objective there is a need to understand the concept of $O C B$ and its various dimensions which may vary from organisation to organisation and from region to region. This paper makes an attempt to revalidate the scale of Organ's five-factor model and to have the better understanding of banking employees with regard to OCB. A five-point Likert scale has been used on a sample of 602. Exploratory Factor Analysis and Confirmatory Factor Analysis were applied to determine different factors of OCB in select banks in Jammu \& Kashmir state of India. This entire sample was utilized for measuring the content, construct, convergent and discriminant validity and reliability of this instrument. EFA and CFA supported this five factor model of OCB namely Altruism, Conscientiousness, Civic Virtue, Courtesy and Sportsmanship. This paper concluded and recommended that this $O C B$ scale is regarded as a reliable instrument which can be of great utility for practitioners and academicians in the field of citizenship behaviour.

Keywords: Organisational Citizenship Behaviour, Exploratory Factor Analysis, Confirmatory Factor Analysis

\section{Introduction}

In today's environment, organisations are looking for competitive advantage, increased efficiency, profitability and finding new ways to increase employee's efforts. It is also believed that the smooth functioning of the organisation largely depends upon employee's extra efforts that are beyond their official job requirements (Organ, 1988). Thus, it is imperative to investigate the behaviour of employees in organisational settings as their behaviour contributes significantly towards an organisation's growth. When employees demonstrate positive behaviours which are outside the scope of their contractual obligations are more specifically called as Organisational Citizenship Behaviour (OCB). It is also referred as "the extra discretionary advantageous, tangible and intangible activities and behaviours that are result of effective workplace relationships" (Podsakoff, MacKenzie, Paine and Bachrach, 2000). Organisations need employees who can voluntarily put in extra effort and behave as good citizens by displaying all sorts of positive behaviour in the 
workplace. As relationships are formed reciprocity also develops, which gives a positive environment in which employees help each other and goes beyond the call of their job.

Earlier, employees were evaluated on the basis of their job description and duties assigned to them. But, today's scenario is different as their performance in the organisation is evaluated on the basis of what they do beyond that which is an enforceable requirement of the job description (Bolino \& Turley, 2003). Moreover, there are several studies which have shown the development of OCB research into other areas of management, like human resource management, leadership and strategic management. OCB has been distinguishably contributing towards organisational outcomes, like service quality (Bettencourt \& Brown, 1997; Bell \& Menguc, 2002), organisational commitment (Podsakoff, McKenzie \& Bommer, 1996), job involvement (Dimitriades, 2007), and leader-member exchange (Bhal, 2006; Lo, Ramayah \& Jerome, 2006).

The topic of OCB has drawn an extensive amount of scholarly attention (reviews were given by Podsakoff, MacKenzie, Paine \& Bachrach, 2000) and these behaviours contribute to the effective functioning of the organisation (Podsakoff, Ahearne \& MacKenzie, 1997; Podsakoff \& MacKenzie, 1994). OCB is essential because organisations cannot forecast, through formally stated in-role job descriptions, the entire range of behaviours needed for achieving goals (George \& Brief, 1992). It has been shown by many studies that OCB has a positive impact on organisational success as it affects the productivity, enhance the performance of employees, better utilisation of resources, employee stability and adaptability to the changes.

The banking industry is regarded as the backbone of any country's economy. As service provider, their performance is evaluated on the basis of the number of customers it's able to retain. These employees are regarded as the image maker as their behaviour in the organisation influences the perception of the customers towards the service organisations. It is widely recognised that the way an organisation treats employees is reflected in the same way those same employees treat customers (Bowen, 1996; Bowen, Gilliland, \& Folger, 1999; Podsakoff \& MacKenzie, 1997).So, having effective and efficient employees who are able to provide superior customer service is a precondition. Generally the most of the research on OCB were carried out in western countries where environment, values, culture, norms are different from Indian contexts. In addition, Al-sharafi and Rajiani (2013) also suggested that there is need to conduct OCB studied in different contexts and apply their findings appropriately. However, few dimensions of OCB are related across different contexts while others are specific to particular contexts. As this study is conducted in India, the research focus is on two largest banks in Jammu \& Kashmir (J\&K), i.e. State Bank Of India (SBI) and Jammu and Kashmir Bank (J\&K Bank).The present study seeks to explore the different dimension of OCB and also to have the better understanding of banking employees with regard to OCB.

\section{Organisational Citizenship Behaviour: An Exploration through Literature}

Organisational Citizenship Behaviour (OCB) -- those behaviours which are not imposed by the organisation as they are not specified in their job description but 
based on the employee's discretion to work voluntarily for the smooth functioning of the organisation. Bateman and Organ (1983) and Smith, Organ and Near (1983) proposed the concept of organisational citizenship behaviour based on the notion of "willingness to cooperate" described by Barnard (1938) and "extra role behaviour" illustrated by Katz (1964) and Katz and Kahn (1966).By 1988's, Dennis W. Organ and a colleague first introduced a formal definition of Organisational citizenship behaviour as : 'individual behaviour that is discretionary, not directly or explicitly recognised by the formal reward system, and that in the aggregate promotes the effective functioning of the organisation'. From the above definition, it can be derived that OCB is an extra role behaviour which is neither punishable nor obligatory thus improves the performance of the organisation.

OCB is imperative in organisational context. Organ (1994) stated that organisations cannot function effectively without the benefit of OCB. When employees goes further than their prescribed role without any desire for incentives will make organisations functioning smooth and cost effective. Research has shown strong correlation of OCB with employee effectiveness (Yen \& Niehoff, 2004) and organisational success (Podsakoff \& MacKenzie, 1994). Today, organisations are heavily dependent on the efforts of employees to take initiative in displaying OCBs (Griffin, Neal, \& Parker, 2007; Bowler, Halbesleben, \& Paul, 2010). The employees depict different behaviour in organisational setting, some does the least just to validate their membership and some exceed the expectations and engaged themselves in extra-role behaviours to assist the organisation in achieving its goals or to benefit others including employees and customers (Van Dyne, Cummings, \& Parks, 1995). These extra-role behaviours are advantageous to the organisation as employees themselves want to do more than what is required of them. In this regard, Aquinis (2013) also states that it is not easy for an organisation to achieve competitive advantage if employees do not carry out OCB.

OCB has intense impact on organisations as well as on individuals; that is why organisations are today interested in envisaging OCB and rewarding these behaviours. The research in this area has increased significantly over the years (Podsakoff, MacKenzie, Paine, \& Bachrach, 2000). Kinicki and Kreitner (2008) defined OCB as behaviours consisting of employees behaviours that are beyond the call of duty. It includes positive attitudes of employees with regard to their organisation, punctuality, willing to do extra for the department, suggestions for improvement, treating organisational property with care. It is an acceptable fact that employees engage themselves in such behaviours(OCBs) only when they feel wanted in the organisation (Chiang \& Hsieh, 2012). Moreover, Organ (1988; 1997) argued that when employees experience positive treatment from key organisational representatives, social exchanges and reciprocity norms influence incumbents to demonstrate OCBs in an effort to informally compensate this treatment. This Social exchange theory has served as the theoretical principle underpinning of the citizenship literature (Kacmar et al., 2012). As per this theoretical framework, employees engage in positive behaviour like OCB when they feel themselves wanted by their organisation and reciprocate in the same way. This behaviour of employee is effective for the organisation because it is their discretionary behaviour which is not insisted on them by any formal contract. OCB is something which is unexpected and cannot be taught by any formal training. However, research has also shown that this 
type of behaviour is desirable due to its positive effect on the organisation and workers (Inatraprasong et al., 2012).

OCB is also very important for organisational continuity (Bergeron et al., 2011; Mohanty \& Rath, 2012; Nielsen et a., 2012; Noor, 2009; Yaghoubi, Mashinchi, \& Hadi, 2010; Özturk, 2010). Since it is not possible for an organisation to forecast and control the external environment but they can access and obtain the extra benefits internally which is evident for its survival. An extra-role behaviour or OCB is not under any specific job description, not under any formal reward system, not compulsory, unexpected, and could provide extra benefits in addition to benefits derived from expected role specific behaviour (Swaminathan \& Jawahar, 2013). It also has a strong association with organisational culture, organisational commitment and job motivation (Intaraprasong, Dityen, Krugkrunjit, \& Subhadrabandhu, 2012). Employees who depict low level of OCB are more likely to leave the organisation and also have a low tendency of innovation and creativity than those exhibiting higher level of OCBs (Mohammad, Habib, \& Alias, 2011). It is also observed that employees who exhibit OCB have higher performance (Wang \& Baum, 2008) and are more committed (Nielsen, Bachrach, Sundstrom, \& Half hill, 2012). Employees having high level of commitment are motivated to exhibit OCB (Bergeron et al., 2011; Noor, 2009). Thus high level of OCB can draw our focus on other positive aspects also.

Researchers have classified OCB in various dimensions. For instance, Smith et al. (1983) identified two types of organisational citizenship behaviours to include altruism (benevolence) and generalized compliance (adherence to rules). However, Organ's (1988) conceptualisation of OCB includes five behaviour types (mentioned in Table 1) - altruism, courtesy, sportsmanship, conscientiousness and civic virtueall necessary for effective organisations and enhancing effectiveness of the organisations. The generalised compliance dimension was submerged into conscientiousness while altruism was retained as originally proposed.

Table1 Five-Factor Model of OCB Dimensions and Definitions

\begin{tabular}{|c|c|c|}
\hline Dimension & Description & Business Setting Examples \\
\hline Altruism & $\begin{array}{l}\text { Behaviour that focussed towards helping } \\
\text { other person who have problems regarding } \\
\text { organisational tasks or any other relevant } \\
\text { problems. }\end{array}$ & $\begin{array}{l}\text { Helping co-workers to understand } \\
\text { computer software program, or locate } \\
\text { information. }\end{array}$ \\
\hline Civic Virtue & $\begin{array}{l}\text { Behaviour that involves participating in } \\
\text { organisational life }\end{array}$ & $\begin{array}{l}\text { Attending functions and developments, } \\
\text { monitoring firms threats and } \\
\text { opportunities, attending company- } \\
\text { sponsored social events. }\end{array}$ \\
\hline Conscientiousness & $\begin{array}{l}\text { Behaviour that goes beyond the minimum } \\
\text { job requirement or expectation }\end{array}$ & $\begin{array}{l}\text { Being punctual, not taking extra breaks, } \\
\text { reserving organizational resources }\end{array}$ \\
\hline Courtsey & $\begin{array}{l}\text { Refers to consulting with those whose } \\
\text { work would be affected by one's action }\end{array}$ & $\begin{array}{l}\text { Giving advance notice when not able to } \\
\text { come, notify co-workers in advance of } \\
\text { committing to actions that will affect } \\
\text { them. }\end{array}$ \\
\hline Sportsmanship & $\begin{array}{l}\text { Behaviour which refers to tolerating trivial } \\
\text { matters and inconveniences without } \\
\text { complaining. }\end{array}$ & $\begin{array}{l}\text { Avoiding complaining about having to } \\
\text { work overtime to complete a project, } \\
\text { minor grievances etc. }\end{array}$ \\
\hline
\end{tabular}


On the basis of Organ's classification, William and Anderson (1991) identified three dimensions of OCB which includes in-role behaviours (IRB), organisational citizenship behaviour directed at the organisation (OCBO) and organisational citizenship behaviour directed towards individuals within the organisation (OCBI). The in-role behaviours represent stipulated duties contained in the job description and employment contract which is similar to the role performance posited by Katz (1964). OCB-O was defined as a behaviour that is directed towards benefiting the organisation as a whole and includes conscientiousness, sportsmanship and civicvirtue. On the other hand, OCB-I includes those behaviours that are directed towards specific individuals but it benefits the organisation indirectly and includes courtesy and altruism.

Moreover, literature suggests various dimensions of OCB, namely Participation, Loyalty, and Obedience and Functional participation (Van Dyne, Graham, and Dienesch , 1994), loyal boosterism, personal industry, individual initiative (Moorman \& Blakely, 1995), Helping Behavior, Sportsmanship, Organizational loyalty, Organizational compliance, Individual initiative, Civic virtue, Selfdevelopment (Ozturk, 2011). Although, the present study is based on five-factor model of OCB (Organ, 1998).

\section{Research Methodology}

The present study was conducted to revalidate the Organ's five factor model of OCB. This scale was analysed in the banking sector with certain modifications. Methodology includes participants and procedures, reliability, validity, exploratory factor analysis and confirmatory factor analysis. A detailed description of all these are as follows

\subsection{Participants and Procedure}

This study was conducted on employees of Jammu \& Kashmir Bank (J\&K Bank) and State Bank of India (SBI) in the state of J\&K. Organ's five factor model of organisational citizenship behaviour scale with modifications was used specifically for the banking employees. The five dimensions of OCB are Altruism, Civic Virtue, Conscientiousness, Courtesy, Sportsmanship which requires due consideration of issues of scale type and validity.

A thorough review of literature was done to develop a comprehensive understanding of Organisational Citizenship Behaviour dimensions. A total of 31 items mentioned in Table 2 were generated by using 5-point Likert scale which ranges from strongly disagree to strongly agree.

As discussed earlier, the target population for this study comprised of employees of two largest banks in the state of J\&K i.e. SBI and J\&K Bank. As sample size affects the reliability of factor analysis and thus total sample size comes out to be 700. For selecting branches of the select banks and respondents, a convenience sampling technique was used. Final questionnaire were administered to 750 employees out of which 700 questionnaires were found to be valid and filled. Thereby, after the deletion of all the outliers final sample size comes out to be 602 . Thus, final analysis was done through SPSS 16.0 on the sample of 602 respondents.

Before conducting EFA for data purification, reliability and KMO-Bartlett test of Sphericity of this instrument was checked. 
Table 2 Organisational Citizenship Behaviour and its Dimensions

\begin{tabular}{|c|c|c|}
\hline S.No & Statements & Titles \\
\hline 1 & I stay in line with the changes in the organisation. & Sportsmanship (Sport) \\
\hline 2 & I help my colleagues when they are absent. & Altruism (Al) \\
\hline 3 & I move with the organizational developments. & Civic Virtue (CV) \\
\hline 4 & $\begin{array}{l}\text { I voluntarily did extra than what is required so that I can help others or } \\
\text { contribute positively in the functioning of the organisation. }\end{array}$ & Sportsmanship(Sport) \\
\hline 5 & $\begin{array}{l}\text { I show punctuality at work by coming on time in the morning and after } \\
\text { breaks. }\end{array}$ & $\begin{array}{l}\text { Conscientiousness } \\
\text { (CONS) }\end{array}$ \\
\hline 6 & $\begin{array}{l}\text { I am willing to attend meetings that are not compulsory, but are considered } \\
\text { essential for the organization or department. }\end{array}$ & Civic Virtue (CV) \\
\hline 7 & I believe in an honest pay for an honest work. & $\begin{array}{l}\text { Conscientiousness } \\
\text { (CONS) }\end{array}$ \\
\hline 8 & I try not to affect my colleagues' work with my actions. & Courtesy (CORTS) \\
\hline 9 & I am always ready to help those who are in need. & Altruism $(\mathrm{Al})$ \\
\hline 10 & I read and keep up with banks notices, memos rapidly. & Civic Virtue (CV) \\
\hline 11 & I don't pin point mistakes with what the bank is doing. & Sportsmanship (Sport) \\
\hline 12 & I complete my work on time. & $\begin{array}{l}\text { Conscientiousness } \\
\text { (CONS) }\end{array}$ \\
\hline 13 & I don't misuse the right of other members of the bank. & Courtesy (CORTS) \\
\hline 14 & I have never worked less than required without supervision. & $\begin{array}{l}\text { Conscientiousness } \\
\text { (CONS) }\end{array}$ \\
\hline 15 & I never volunteer for extra work and do what is just required. & $\begin{array}{l}\text { Sportsmanship } \\
\text { (SPORT) }\end{array}$ \\
\hline 16 & I often share my personal things with others who need them in their work. & Altruism $(\mathrm{Al})$ \\
\hline 17 & I always take care of company's assets. & Courtesy (CORTS) \\
\hline 18 & I train or help other members in their jobs. & Altruism $(\mathrm{Al})$ \\
\hline 19 & I actively promote bank's products and services. & Civic Virtue (CV) \\
\hline 20 & $\begin{array}{l}\text { I always comply by banks rules and regulations even when no one is } \\
\text { inspecting. }\end{array}$ & $\begin{array}{l}\text { Conscientiousness } \\
\text { (CONS) }\end{array}$ \\
\hline 21 & I don't pay attention or waste my time in complaining about small matters. & $\begin{array}{l}\text { Sportsmanship } \\
\text { (SPORT) }\end{array}$ \\
\hline 22 & $\begin{array}{l}\text { I show actual concern and courtesy toward my colleagues' job related or } \\
\text { personal problems. }\end{array}$ & Courtesy (CORTS) \\
\hline 23 & I am willing to do extra work when completed the given work. & Altruism $(\mathrm{Al})$ \\
\hline 24 & My attendance at work is my priority. & $\begin{array}{l}\text { Conscientiousness } \\
\text { (CONS) }\end{array}$ \\
\hline 25 & $\begin{array}{l}\text { I attend training/ information session that I am expected to, but not } \\
\text { compulsory to attend. }\end{array}$ & Civic Virtue (CV) \\
\hline 26 & $\begin{array}{l}\text { I try to improve organisation's image through disciplining one's own } \\
\text { behavior in public. }\end{array}$ & Courtesy (CORTS) \\
\hline 27 & $\begin{array}{l}\text { I am ready to take steps in order to protect the reputation of my } \\
\text { organization. }\end{array}$ & Civic Virtue (CV) \\
\hline 28 & $\begin{array}{l}\text { I make serious efforts in my work and do things with sense of responsibility } \\
\text { even when it does not make any effect in my performance appraisal. }\end{array}$ & $\begin{array}{l}\text { Conscientiousness } \\
\text { (CONS) }\end{array}$ \\
\hline 29 & I always focus on what's wrong, rather than the positive side. & $\begin{array}{l}\text { Sportsmanship } \\
\text { (SPORT) }\end{array}$ \\
\hline 30 & $\begin{array}{l}\text { I willingly help my colleagues who have some problems related towards } \\
\text { their work }\end{array}$ & Altruism (Al) \\
\hline 31 & $\begin{array}{l}\text { Despite of any situation, I am extremely courteous and respectful to } \\
\text { customers. }\end{array}$ & Courtesy (CORTS) \\
\hline
\end{tabular}




\subsection{Reliability Test}

Reliability test is the basic requirement to move further with the present research. For that Chronbach alpha is the prerequisite to check the internal consistency of the scale. The reliability of the scale was found to be 0.92 in Table 3 , which is more than minimum requirement of 0.7 . The test results show that this instrument has good stability and consistency.

Table 3 Reliability Statistics

\begin{tabular}{|c|c|}
\hline Cronbach's Alpha & N of Items \\
\hline .92 & 31 \\
\hline
\end{tabular}

The value of KMO should lies between 0 to 1 . According to Hutcheson and Sofroniou (1999), KMO value within .5 to .7 are average, .7 and .8 are good, .8 and .9 are great above .9 is outstanding. For this instrument KMO comes out to be .875 (mentioned in Table 4) which is good and the principal component analysis was run. Barlett's Test was highly significant as $\mathrm{p}<.005$, which was good to further move for factor analysis.

Table 4 KMO and Bartlett's Test

\begin{tabular}{|l|c|c|}
\hline Kaiser-Meyer-Olkin Measure of Sampling Adequacy & $\mathbf{. 8 7 5}$ \\
\hline \multirow{3}{*}{ Bartlett's Test of Sphericity } & Approx. Chi-Square & $1.879 \mathrm{E} 4$ \\
\cline { 2 - 3 } & Df & 465 \\
\cline { 2 - 3 } & Sig. & .000 \\
\hline
\end{tabular}

\subsection{Exploratory Factor Analysis}

Exploratory factor analysis was undertaken on the 31 items of employee OCB construct. Varimax rotation was administered and these factors collectively explain 76.098 of the total variance which is shown in Table 5 .

From the above Table, it can be seen that 31 items were extracted into five different components. All commonalities that were extracted were greater than 0.5 .

Table 6 summarises the 31 employee OCB variables into 5 factors. The first component was termed as Altruism comprised of 6 statements which describes the helping behavior of employees towards their co-worker. The second factor includes 7 items of Conscientiousness that explains employees' adherence to expected standards. The third component is Sportsmanship which includes 6 items that speaks about tolerance and risk taking. The fourth factor is Civic Virtue which comprised of 6 items that describes the voluntary effort of the employees, and the last fifth component is Courtesy that includes 6 statements that explains the genuine concern of the employees towards the co-worker and the organisation.

\subsection{Demographic Profile of the Participants}

The demographic profile of the focal group is shown in Table 7 which reveals that the sample is predominantly of males ( 57 per cent), with tenure above 20 years (37 per cent), mostly are graduates (42 per cent), with annual income of 300000-600000 (37 per cent), maximum are from officer scale (76 per cent) from both SBI (49 per cent) and J\&K Bank (50 per cent). 
Table 5 Total Variance Explained

\begin{tabular}{|c|c|c|c|c|c|c|c|c|c|c|}
\hline \multirow{2}{*}{ Component } & \multicolumn{3}{|c|}{ Initial Eigen values } & \multicolumn{3}{|c|}{$\begin{array}{l}\text { Extraction Sums of Squared } \\
\text { Loadings } \\
\end{array}$} & \multicolumn{3}{|c|}{$\begin{array}{c}\text { Rotation Sums of Squared } \\
\text { Loadings } \\
\end{array}$} & \multirow[t]{2}{*}{ Extraction } \\
\hline & Total & $\begin{array}{c}\% \text { of } \\
\text { Variance }\end{array}$ & $\begin{array}{c}\text { Cumulative } \\
\%\end{array}$ & Total & $\begin{array}{c}\% \text { of } \\
\text { Variance }\end{array}$ & $\begin{array}{c}\text { Cumulative } \\
\%\end{array}$ & Total & $\begin{array}{c}\% \text { of } \\
\text { Variance }\end{array}$ & $\begin{array}{c}\text { Cumulative } \\
\%\end{array}$ & \\
\hline 1 & 16.588 & 53.509 & 53.509 & 16.588 & 53.509 & 53.509 & 5.359 & 17.287 & 17.287 & 0.9501986 \\
\hline 2 & 2.531 & 8.165 & 61.674 & 2.531 & 8.165 & 61.674 & 5.344 & 17.238 & 34.525 & 0.8315728 \\
\hline 3 & 1.83 & 5.902 & 67.576 & 1.83 & 5.902 & 67.576 & 4.933 & 15.913 & 50.439 & 0.8815673 \\
\hline 4 & 1.448 & 4.672 & 72.248 & 1.448 & 4.672 & 72.248 & 4.502 & 14.523 & 64.961 & 0.7776051 \\
\hline 5 & 1.193 & 3.85 & 76.098 & 1.193 & 3.85 & 76.098 & 3.452 & 11.137 & 76.098 & 0.8431095 \\
\hline 6 & 0.677 & 2.183 & 78.282 & & & & & & & 0.8445359 \\
\hline 7 & 0.553 & 1.783 & 80.064 & & & & & & & 0.7261372 \\
\hline 8 & 0.493 & 1.591 & 81.655 & & & & & & & 0.6700301 \\
\hline 9 & 0.464 & 1.498 & 83.153 & & & & & & & 0.7679246 \\
\hline 10 & 0.43 & 1.387 & 84.54 & & & & & & & 0.7475791 \\
\hline 11 & 0.4 & 1.29 & 85.83 & & & & & & & 0.7451777 \\
\hline 12 & 0.363 & 1.17 & 87.001 & & & & & & & 0.7151763 \\
\hline 13 & 0.346 & 1.116 & 88.117 & & & & & & & 0.6671293 \\
\hline 14 & 0.332 & 1.072 & 89.189 & & & & & & & 0.867692 \\
\hline 15 & 0.299 & 0.965 & 90.154 & & & & & & & 0.7919514 \\
\hline 16 & 0.291 & 0.938 & 91.092 & & & & & & & 0.7791077 \\
\hline 17 & 0.284 & 0.916 & 92.008 & & & & & & & 0.7986381 \\
\hline 18 & 0.279 & 0.898 & 92.907 & & & & & & & 0.5968563 \\
\hline 19 & 0.256 & 0.825 & 93.731 & & & & & & & 0.8709611 \\
\hline 20 & 0.241 & 0.778 & 94.51 & & & & & & & 0.7211253 \\
\hline 21 & 0.226 & 0.729 & 95.239 & & & & & & & 0.694648 \\
\hline 22 & 0.222 & 0.715 & 95.954 & & & & & & & 0.717825 \\
\hline 23 & 0.2 & 0.645 & 96.599 & & & & & & & 0.7670993 \\
\hline 24 & 0.189 & 0.609 & 97.208 & & & & & & & 0.6447004 \\
\hline 25 & 0.178 & 0.575 & 97.782 & & & & & & & 0.6467445 \\
\hline 26 & 0.163 & 0.524 & 98.307 & & & & & & & 0.7675859 \\
\hline 27 & 0.152 & 0.491 & 98.798 & & & & & & & 0.7532004 \\
\hline 28 & 0.125 & 0.402 & 99.2 & & & & & & & 0.7672553 \\
\hline 29 & 0.118 & 0.379 & 99.579 & & & & & & & 0.7228999 \\
\hline 30 & 0.093 & 0.302 & 99.881 & & & & & & & 0.7483738 \\
\hline 31 & 0.037 & 0.119 & 100 & & & & & & & 0.7660796 \\
\hline
\end{tabular}

\section{Extraction Method: Principal Component Analysis}

\subsection{Confirmatory Factor Analysis}

After factor analysis, the next step is to confirm the factors through confirmatory factor analysis in order to develop a more valid factorial structure of OCB. CFA is widely used to test whether the data fit a hypothesised measurement model. Through exploratory factor analysis five factors were emerged i.e. Altruism, Conscientiousness, Civic Virtue, Courtesy and Sportsmanship; CFA was performed in data using AMOS.16. CFA was conducted on 31 items and model fit was assessed 
using indicators like Chi-Square measure, Non-Normed Fit Index (NFI), Comparative Fit Index (CFI), Root Mean Square Residual (SRMR), Goodness-of-fit index (GFI) and Root Mean Square Error of Approximation (RMSEA). Relatively Chi-Square should be less than 3; NFI should be greater than 0.95; CFI should be greater than 0.95;GFI should be greater than 0.95; AGFI should be greater than 0.80 and RMSEA should be less than 0.08 (Hair et al.,2010).

Table 6 Rotated Component Matrix

\begin{tabular}{|l|c|c|c|c|c|}
\hline & \multicolumn{5}{|c|}{ Component } \\
\hline & 1 & 2 & 3 & 4 & 5 \\
\hline AL1 & 0.888 & & & & \\
\hline AL2 & 0.819 & & & & \\
\hline AL3 & 0.846 & & & & \\
\hline AL4 & 0.799 & & & & \\
\hline AL5 & 0.844 & & & & \\
\hline AL6 & 0.852 & & & & \\
\hline CONS1 & & 0.704 & & & \\
\hline CONS2 & & 0.714 & & & \\
\hline CONS3 & & 0.725 & & & \\
\hline CONS4 & & 0.746 & & & \\
\hline CONS5 & & 0.763 & & & \\
\hline CONS6 & & 0.732 & & & \\
\hline CONS7 & & 0.697 & & & \\
\hline SPORT1 & & & 0.82 & & \\
\hline SPORT2 & & & 0.798 & & \\
\hline SPORT3 & & & 0.703 & & \\
\hline SPORT4 & & & 0.782 & & \\
\hline SPORT5 & & & 0.679 & & \\
\hline SPORT6 & & & 0.825 & & \\
\hline CV1 & & & & & 0.559 \\
\hline CV2 & & & & & 0.763 \\
\hline CV3 & & & & & 0.612 \\
\hline CV4 & & & & & 0.635 \\
\hline CV5 & & & & & 0.684 \\
\hline CV6 & & & & & 0.567 \\
\hline CORTS1 & & & & 0.756 & \\
\hline CORTS2 & & & & 0.717 & \\
\hline CORTS3 & & & & 0.694 & \\
\hline CORTS4 & & & & 0.679 & \\
\hline CORTS5 & & & & 0.74 & \\
\hline CORTS6 & & & & 0.762 & \\
\hline
\end{tabular}

Extraction Method: Principal Component Analysis Rotation Method: Varimax with Kaiser Normalization

However, even if CFI and NNFI indicated acceptable fit value (CFI=.949 and $\mathrm{NFI}=.928$ ), other measure in first CFA did not result in satisfactory fit indexes $(\mathrm{CMIN} / \mathrm{DF}=3.224, \mathrm{SRMR}=.024$ and RMSEA=.061). These results indicated the need for some modification to make the model best fit. The output of CFA suggested 
regression paths of four pairs of items (AL2-AL4, SPORT2-SPORT6, SPORT3SPORT5, CV2-CV5). After these modification, Table 8 shows the CFA with 31 items which were re-run to identify the model that represents the best fit. Five factors were emerged and results indicated the value of $\mathrm{CMIN} / \mathrm{DF}=1.942, \mathrm{RMR}=.023$, $\mathrm{GFI}=0.918$, AGFI=0.904, $\mathrm{CFI}=0.979, \mathrm{NFI}=0.957$ and $\mathrm{RMSEA}=0.40$. The below model is in line with Hair et al (2010) and shows an excellent fit.

Table 7 Demographic Profile of the Respondents

\begin{tabular}{|c|c|c|c|}
\hline Factor & & No. of Respondents & Percentage \\
\hline \multirow{2}{*}{ Organization } & SBI & 297 & 49.33 \\
\hline & $\mathrm{J} \& \mathrm{~K}$ Bank & 305 & 50.66 \\
\hline \multirow{2}{*}{ Designation } & scale 1 (Clerical level) & 294 & 48.83 \\
\hline & scale 2 (Officer level) & 308 & 51.16 \\
\hline \multirow{4}{*}{ Qualification } & 10th-12th & 13 & 2.159 \\
\hline & graduation & 328 & 54.48 \\
\hline & post graduation & 256 & 42.52 \\
\hline & above post graduation & 5 & 0.830 \\
\hline \multirow{4}{*}{ Income } & Up to Rs 3lakhs & 89 & 14.78 \\
\hline & Rs3 lakhs-Rs6 lakhs & 226 & 37.54 \\
\hline & Rs 6 lakhs- Rs 9 lakhs & 213 & 35.38 \\
\hline & above 9 lakhs & 74 & 12.29 \\
\hline \multirow{5}{*}{ Tenure } & $0-5 \mathrm{yrs}$ & 174 & 28.90 \\
\hline & 6-10yrs & 80 & 13.28 \\
\hline & $11-15 y r s$ & 71 & 11.79 \\
\hline & $16-20 y r s$ & 47 & 7.807 \\
\hline & above $20 \mathrm{yrs}$ & 230 & 38.20 \\
\hline \multirow{2}{*}{ Gender } & Male & 344 & 57.14 \\
\hline & female & 257 & 42.69 \\
\hline
\end{tabular}

Table 8 Model Fit Indices

\begin{tabular}{|l|c|}
\hline \multicolumn{1}{|c|}{ Measure } & Threshold value \\
\hline Chi- square/df & 1.942 \\
\hline Goodness of fit(GFI) & 0.918 \\
\hline Adjusted Goodness of fit (AGFI) & 0.904 \\
\hline Normed Fit Index & 0.957 \\
\hline Root Mean Square Error of Approximation (RMSEA) & 0.40 \\
\hline
\end{tabular}

The model is consistent with the above theoretical arguments, the concept of Organisational Citizenship Behaviour was operationalized as a second-order construct manifested in five dimensions, i.e., Altruism, Conscientiousness, Civic Virtue, Courtesy and Sportsmanship. 


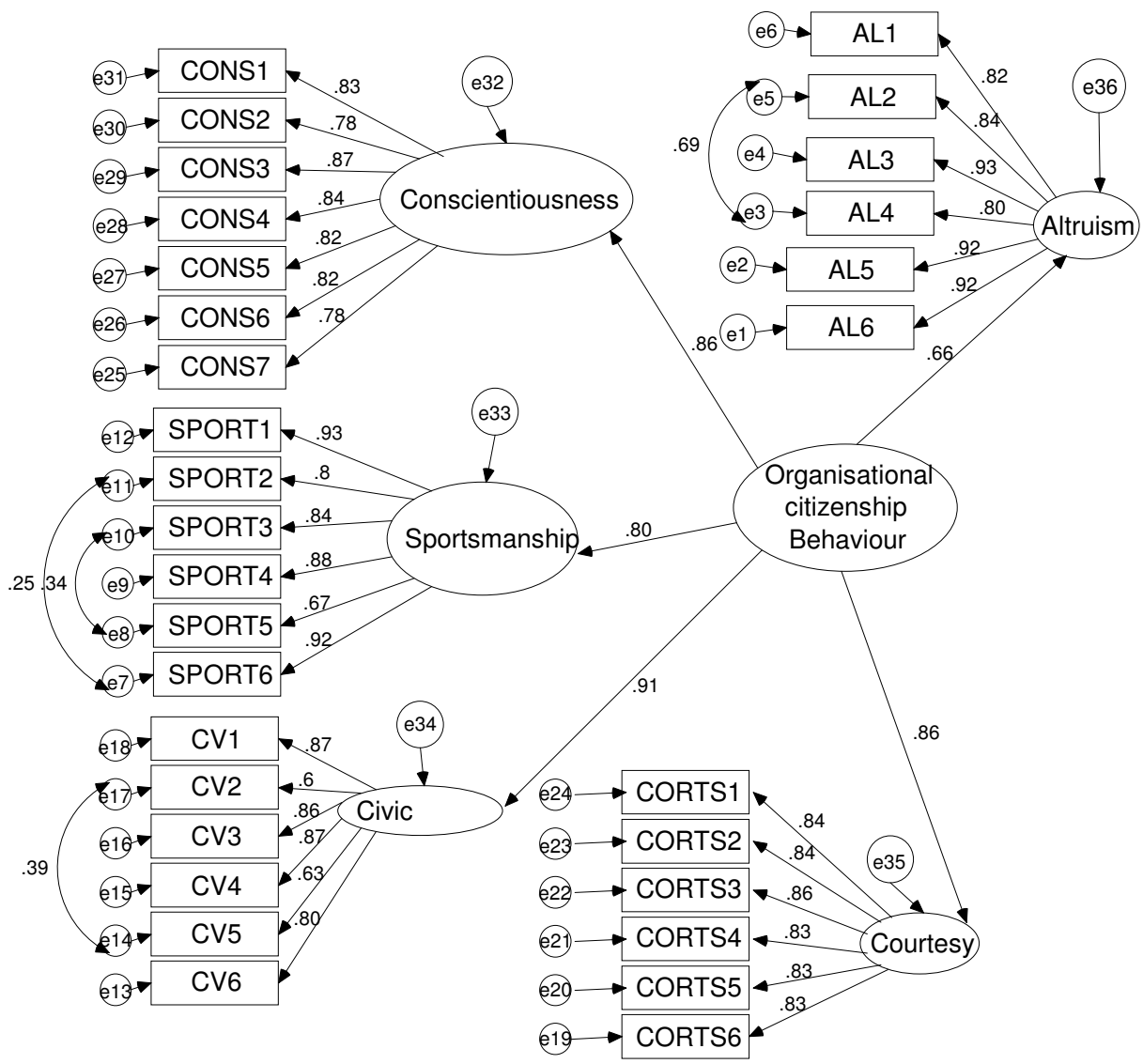

Figure 1 Organ's Five Factor Scale to Measure Organisational Citizenship Behaviour Note: - AL-Altruism, Cons-Conscientiousness, SPORT-Sportsmanship, CV-Civic Virtue, CORTS-Courtesy

\section{Results}

It is important to analyse the reliability and validity of the construct after analysing its statistics of model fit.

\subsection{Assesing Reliability}

Cronbach Alpha was used to check the internal consistency and to determine whether the items of OCB are consistent with each other or not. For that reliability analysis for each factor was performed using SPSS 16.0 version. As per Nunnally (1978; 1988), who suggested cut-off value of 0.5 is important for measuring the internal consistency. However, from Table 9, it can be seen that Alpha values for each five factor are above 0.8 which is satisfactory. 
Table 9 Assessing Reliability

\begin{tabular}{|l|c|}
\hline \multicolumn{1}{|c|}{ Factors } & Reliability \\
\hline Altruism & .894 \\
\hline Conscientiousness & .879 \\
\hline Sportsmanship & .889 \\
\hline Civic Virtue & .871 \\
\hline Courtesy & .878 \\
\hline
\end{tabular}

\subsection{Assesing Convergent Validity}

Convergent validity refers to the degree to which any two or more measures are related to each other. For analysing convergent validity there are few predetermined conditions: i) Composite Reliability should be greater than 0.7, ii) Average variance extracted should be greater than 0.5, iii) Composite Reliability should be greater than Average Variance Extracted (CR $>$ AVE) ( Dash\& Chaudhuri, 2015). From Table 10, it can be seen that all three above mention conditions were satisfied and thus confirmed the convergent validity of this model.

Table 10 Measurement Model: Factor Loadings and Reliability

\begin{tabular}{|l|c|c|c|c|}
\hline \multicolumn{1}{|c|}{ Constructs } & $\begin{array}{c}\text { No. of } \\
\text { Indicators }\end{array}$ & $\begin{array}{c}\text { Range of } \\
\text { Standardized } \\
\text { Factor Loadings }\end{array}$ & $\begin{array}{c}\text { Composite } \\
\text { Reliability }\end{array}$ & $\begin{array}{c}\text { Average Variance } \\
\text { Extracted (AVE) }\end{array}$ \\
\hline Altruism & 6 & $0.799-0.888$ & 0.93 & 0.70 \\
\hline Conscientiousness & 7 & $0.697-0.763$ & 0.88 & 0.52 \\
\hline Sportsmanship & 6 & $0.679-0.825$ & 0.89 & 0.59 \\
\hline Civic Virtue & 6 & $0.567-0.763$ & 0.80 & 0.50 \\
\hline Courtesy & 6 & $0.679-0.762$ & 0.86 & 0.52 \\
\hline
\end{tabular}

\subsection{Assesing Discriminant Validity}

According to Campbell and Fiske (1959) discriminant validity is the extent to which a measure does not correlate with other constructs. Moreover, average variance extracted is greater than square of inter-construct correlation depicting the difference between the factors (Fornell and Larcker, 1981; Hammer at al., 2011; Saade and Bahli, 2005). As per Table 11, discriminant validity provides an acceptable fit to the data.

Table 11 Inter-Item Correlation Matrix

\begin{tabular}{|l|c|c|c|c|c|}
\hline & AL & CONS & SPORT & CV & CORTS \\
\hline AL & 1.000 & - & - & - & - \\
\hline CONS & $.622(\mathbf{0 . 3 9})$ & 1.000 & - & - & - \\
\hline SPORT & $.568(\mathbf{0 . 3 2})$ & $.639(\mathbf{0 . 4 0})$ & 1.000 & - & - \\
\hline CV & $.653(\mathbf{0 . 4 2})$ & $.697(\mathbf{0 . 4 8})$ & $.686(\mathbf{0 . 4 7})$ & 1.000 & - \\
\hline CORTS & $.603(\mathbf{0 . 3 6})$ & $.705(\mathbf{0 . 4 9})$ & $.640(\mathbf{0 . 4 0})$ & $.717(\mathbf{0 . 5 1})$ & 1.000 \\
\hline
\end{tabular}

Note: Figures in Parenthesis Represent the Squared Correlations

Note:-AL-Altruism, Cons-Conscientiousness, SPORT-Sportsmanship, CV-Civic Virtue, CORTS- Courtesy 


\section{Discussion}

Today banks are facing stiff competition and are in the need to continuously grow and develop. Thus, it is evident for the employees to do more than their stated job which is regarded as organisational citizenship behaviour. Moreover, organisations are also required to encourage employees to exhibit citizenship behaviour and identify and acknowledge such behaviours of employees. As these discretionary behaviours are completely desirable voluntary behaviours which are beneficial for both the employees as well as the organisation. The aim of the present study was to develop the scale and understand the dimensions of OCB. The study validates the multidimensionality of OCB and confirms its significance for the employee working in the banks of Jammu and Kashmir, India.

A series of last decade studies was carried out to develop and validate the scale of Organisational Citizenship Behaviour. The initial model checked five first-order factors, namely altruism, conscientiousness, sportsmanship, civic vitrue and courtesy and further the incorporation of these dimensions into a second-order factor termed as organisational citizenship behaviour. This scale has reasonable internal consistency, reliability and validity (in the form of convergent and discriminant validity). Thus, this scale is regarded as a reliable instrument which is compatible with existing literature both in Indian and western contexts (e.g. LePine et al., 2001; Chaitanya and Tripathy, 2001; Kumar and Bakshi, 2009). These theoretical findings are notably imperative and are in consesus with the previous results obtained by the different researchers about the reliability and validity of the scale. It was therefore recommended that this Organ's revalidated scale of OCB can be applicable for studying employees' behaviour in different cultural contexts with large number of samples across various organisations.

\section{Limitation and Direction for Future Research}

Despite the relevance discussed above, this study is restricted in terms of the size of the sample. This study focuses on the select banks i.e. State Bank of India and Jammu \& Kashmir Bank in the state of J\&K only. Moreover, it was found that few employees of both the banks believed that the questionnaire might invade their privacy and thereby exhibited conservative behaviour. Also, in order to develop a more compelling model and to robust the construct validity, different types of samples from different regions can be considered. Besides, future research can be planned to check the validity of this instrument in order to make it more authentic and reliable.

\section{References}

1. Agrawal, R., Rastogi, S. \& Mehrotra, A., 'Customers' perspectives regarding ebanking in an emerging economy', Journal of Retailing and Consumer Services, 16(5), 2009, 340-351.

2. Al-sharafi, H., \& Rajiani, I., 'Promoting Organizational Citizenship Behavior among Employees-The Role of Leadership Practices', International Journal of Business and Management, 8(6), 2013, 47.

3. Barnard, C.I., 'The Functions of the Executive', Cambridge, MA: Harvard University Press, 1938. 
4. Bateman, T. S., \& Organ, D. W., 'Job satisfaction and the good soldier: The relationship between affect and employee citizenship,' Academy of Management Journal, 26, 1983, 587-595.

5. Bell, S. \& Menguc, B., 'The employee-organization relationship, organizational citizenship behaviors, and superior service quality', Journal of Retailing, 78(2), 2002, 131-146.

6. Bergeron, D. M., Shipp, A. J., Rosen, B., \& Furst, S. A., 'Organizational Citizenship Behavior and Career Outcomes: The Cost of Being a Good Citizen’ Journal of Management, 2011, 2-29.

7. Bettencourt, L. A. \& Brown, S. W., 'Contact employees: Relationship among workplace fairness, job satisfaction and prosocial behaviors', Journal of retailing, 73, 1997, 39-61.

8. Bhal, K. T., 'LMX-citizenship behavior relationship: Justice as a mediator', Leadership \& Organization Development Journal, 27(2), 2006, 106-117.

9. Bolino, M. C., Turnley, W. H., \& Bloodgood, J. M., 'Citizenship behavior and the creation of social capital in organizations', Academy of Management Review, 27(4), 2002, 505-522.

10. Bowen, D. E., 'Customers as Substitutes for Leadership', Ph. D. Dissertation, East Lansing, MI: Michigan State University, 1983.

11. Bowen, D. E., S. Gilliland, R. Folger., 'HRM and Service Fairness: How Being Fair with Employees Spills Over to Customers', Organizational Dynamics, 27, 1999, 7-23.

12. Bowler, W. M., Halbesleben, J. R. B., \& Paul, J. R. B., 'If you're close with the leader, you must be a brownnose: The role of leader-member relationships in follower, leader, and coworker attributions of organizational citizenship behavior motives', Human Resource Management Review, 20, 2010, 309-316.

13. Campbell, D. T., \& Fiske, D. W., 'Convergent and discriminant validation by the multitrait-multimethod matrix', Psychological Bulletin, 56, 1959, 81-105.

14. Chaitnya, S.K. \& Tripathi, N., 'Dimensions of organizational citizenship behaviour', Indian Journal of Industrial Relations, 37, 2001, 217-230.

15. Chiang, C.F. \& Hsieh, T.S., 'The impacts of perceived organisational support and psychological empowerment on job performance: The mediating effects of organisational citizenship behaviour', International Journal of Hospitality Management, 31(1), 2011, 180-189.

16. Dash, S; Chaudhuri, M., 'Exploring Factorial Structure of OCB in Large Indian Banks: An Empirical Study of Delhi NCR', IOSR Journal of Business and Management, 17(9), 2015, 96-104.

17. Dimitriades, Z.S., 'The influence of service climate and job involvement on customer oriented organizational citizenship behavior in Greek service organizations: A survey', Employee Relations, 29(5), 2007, 469-491.

18. George JM, Brief AP., 'Feeling good and doing good: a conceptual analysis of the mood at work and organizational spontaneity relationship', Psychological Bulletin, 112, 1992, 310-329.

19. Griffin, M. A., Neal, A., \& Parker, S. K., 'A new model of work role performance: Positive behavior in uncertain and interdependent contexts', Academy of Management Journal, 50, 2007, 327-347. 
20. Hooper, D., Coughlan, J., \& Mullen, M. R., 'Structural equation modelling: Guidelines for determining model fit', Electronic Journal of Business Research Methods, 6, 2008, 53-60.

21. Hutcheson, G. D., and Sofroniou, N., 'The Multivariate Social Scientist: An introduction to generalized linear models', Sage Publications, 1999.

22. Intaraprasong, B., Dityen, W., Krugkrunjit, P., \& Subhadrabandhu, T., 'Job Satisfaction and Organizational Citizenship Behavior of Personnel at One University Hospital in Thailand', Journal of Medical Association Thailand, 95(6), 2012, 102-108.

23. Kacmar, K.M. Bachrach, D.G. Harris, K.H. and Noble, D., 'Exploring the role ofsupervisor trust in the associations between multiple sources of relationship conflict and organisational citizenship behavior', The Leadership Quarterly, 23, 2012, 43-54.

24. Katz, D., 'The motivational basis of organizational behaviour', Behavioural Science, 9(2), 1964, 131-146.

25. Katz, D., Kahn, R.L., The Psychology of Organizations. New York: HR Folks International, 1966.

26. Kinicki, A., \& Kreitner, R., 'Organisational Behaviour. Key concepts, skills and best practices', New York: MacGraw Hill, 2008.

27. Kumar \& Bakhshi., 'Organizational Citizenship Behavior in India: Development of A Scale', International Journal of Organisational Behaviour, 14(1), 2005, 14-25.

28. LePine. J.A., \& Van Dyne, L. I., 'Predicting voice behaviour in work groups', Journal of Applied Psychology, 83, 1998, 853-868.

29. Lo, M. C., Ramayah, T., \& Kueh, J. S. H., 'An Investigation of Leader Member Exchange Effects on Organizational Citizenship Behavior in Malaysia', Journal of Business and Management, 12(1), 2006, 5-23.

30. Mohanty, J., \& Rath, B. P., 'Influence of Organizational Culture on Organization Citizenship Behavior: A Three-Sector Study', Global Journal of Business Research, 6(1), 2012, 65-76.

31. Mohammad, J., Habib, F. Q., \& Alias, M. A., 'Job Satisfaction and Organizational Citizenship Behavior: An Empirical Study at Higher Learning Institutions', Asian Academy of Management Journal, 6(2), 2011, 149-165.

32. Moorman, R.H., \& Blakely, G.L., 'Individualism-collectivism as an individual difference predictor of organizational citizenship behaviour', Journal of Organizational Behavior, 16, 1995, 127-142.

33. Nielsen, T. M., Bachrach, D. G., Sundstrom, E., \& Halfhill, T. R., 'Utility of OCB: Organizational Citizenship Behavior and Group Performance in a Resource Allocation Framework', Journal of Management , 38(2), 2012, 668694.

34. Noor, A., 'Examining Organizational Citizenship Behavior as the Outcome of Organizational Commitment: A Study of University Teachers in Pakistan. The 2nd COMSATS', International Business Research Conference: A Conference for Business, Economics and Behavioral Sciences, November 14, 2009 (ISSN \# 2078-8444). Lahore: Pakistan.

35. Nunnally, J. C., Psychometric Theory. New York: Mcgraw-Hill Publishing, 1978. 
36. Nunnally, J. C., Psychometric Theory. New Jersey: Mcgraw-Hill, Englewood Cliffs, 1988.

37. Organ, D.W., 'Personality and organizational citizenship behavior', Journal of Management, 20, 1994, 465-478.

38. Organ, D.W., 'Organisational citizenship behavior: The good soldier syndrome', Lexington, MA: Lexington Books, 1988.

39. Organ, D.W., 'Organisational citizenship behavior: It's construct cleanup time', Human Performance, 10(2), 1997, 85-97.

40. Özturk, F., 'Determinants of Organizational Citizenship Behavior Among Knowledge Workers: The Role of Job Characteristics, Job Satisfaction, and Organizational Commitment', Graduate Thesis, Master-degree Program in Business Administration. Ankara, Turkey: The Graduate School Social Sciences of Middle East Technical University, 2010.

41. Podsakoff, P. M., \&MacKenzie, S. B., 'Organizational citizenship behaviors and sales unit effectiveness', Journal of Marketing Research, 3(1), 1994, 351-363.

42. Podsakoff, P.M., Ahearne, M., \& MacKenzie, S. B., 'Organizational citizenship behavior and the quantity and quality of work group performance', Journal of Applied Psychology, 82, 1997, 262-270.

43. Podsakoff, P.M., MacKenzie, S.B., \& Bommer, W.H., 'Transformational leader behaviours and substitutes for leadership as determinants of employee satisfaction, commitment, trust, and organizational citizenship behaviours', Journal of Management, 22 (2), 1996, 259-298.

44. Podsakoff, P. M., MacKenzie, S. B., Paine, J. B., \& Bachrach, D. G., 'Organizational citizenship behaviors: A critical review of the theoretical and empirical literature and suggestions for future research', Journal of Management, 2000, 26(3), 513-563.

45. Rioux, S., \& Penner, L.A. (2001). The causes of organizational citizenship behavior: A motivational analysis. Journal of Applied Psychology, 86, 13031314.

46. Smith, C. A., Organ, D. W., \& Near, J. P., 'Organizational citizenship behavior: Its nature and antecedents', Journal of Applied Psychology, 68, 1983, 653-663.

47. Swaminathan, S., \& Jawahar, P. D., 'Job Satisfaction as a Predictor of Organizational Citizenship Behavior: An Empirical Study', Global Journal of Business Research, 2013, 71-80.

48. Tourangeau, A. E., McGillis Hall, L., Doran, D. M., \& Petch, T., 'Measurement of nurse job satisfaction using the McCloskey/ Mueller Satisfaction Scale', Nursing Research, 55, 2006, 128-136.

49. Van Dyne, L., Cummings L. L., \& McLean J. P., 'Extra-role Behaviors: In Pursuit of Construct and Definitional Clarity', Research in Organizational Behavior, 17, 1995, 215-285.

50. Wang, T.H., \& Baum, T., 'Exploring the Relationship between Organizational Culture and Organizational Citizenship Behaviour', Graduate Thesis, Masterdegree Program in International Hospitality Management. Glasgow, UK: University of Strathclyde, 2008.

51. Williams L.J., \& Anderson, S.E., 'Job satisfaction and organizational commitment as predictors of organizational citizenship and in-role behaviors', Journal of Management, 17(3), 1991, 601-617. 
52. Yen, H. R. \& Niehoff, B. P., 'Organizational citizenship behaviors and organizational effectiveness: Examining relationships in Taiwanese banks', Journal of Applied Social Psychology, 34(8), 2004, 1617-1637.

\section{About Our Authors}

Parul Mahajan has 3.8 years of experience in academics. She did MBA in HR and Marketing from University of Jammu and is presently pursuing PhD. She has presented various research papers in National and International conferences. Her research interest areas are Emotional Intelligence, Organisational Citizenship Behaviour, Leadership, Women Entrepreneurs. 